\title{
THE IMPACT OF ASEAN-CHINA FREE TRADE AREA (ACFTA) AGREEMENT ON INDONESIA'S MAJOR PLANTATION EXPORT COMMODITIES
}

\author{
Erlambang Budi DARMANTO ${ }^{*}$, Rossanto Dwi HANDOYO², Wisnu WIBOWO \\ ${ }^{1}$ Faculty of Economics, Yos Sudarso University, Surabaya, Indonesia \\ 2, ${ }^{3}$ Department of Economics, Airlangga University, Surabaya, Indonesia
}

Received 23 July 2019; accepted 23 June 2020

\begin{abstract}
This study aims to analyze the impact of ASEAN-China Free Trade Area (ACFTA) on the 4 major exports of plantation commodities (including the commodities of coffee, cocoa, rubber, and palm oil) in Indonesia. The trade impact is measured based on the occurrence of trade creation or trade diversion. The negative coefficient as the result of dummy FTA (Free Trade Area) measurement indicates the presence of trade diversion. Meanwhile, the positive coefficient indicates the presence of trade creation. This study examines the export of major plantation commodities of Indonesia to China and compared with the 10 major export destination countries worldwide. The findings show that trade creation exists within the commodities of coffee, rubber, and palm oil while the trade diversion exists in the commodity of cocoa.
\end{abstract}

Keywords: ACFTA, trade creation, trade diversion, dummy FTA.

JEL Classification: F10, O53, Q17.

\section{Introduction}

The concept of the free market begins with the initiatives of the interregional free trade agreement that has similarities, whether geographically or demographically, including ACFTA (ASEAN-China Free Trade Area). The free trade agreement constitutes an agreement to reduce government protection in forms of import tariffs and export tax for some commodities including plantation commodities. In 2010 , AFTA had reduced about $90-95 \%$ of the tariffs between ASEAN countries into about only 0-5\% (Okabe, 2014).

It has been recognized that a prominent commodity, the era of an open economy through international trade, has made competition between countries increasingly tighter. Every country, including Indonesia, is trying to continue to increase the quantity and quality of its exports. Indonesia's exports to international markets consist of various commodities. The export performance of Indonesian agricultural commodities has shown positive growth, particularly in the plantation subsector.

The plantation sub-sector as a potential export for Indonesia is palm oil through palm oil commodities, coffee beans through raw coffee beans (not roasted), rubber through raw rubber commodities and cocoa through cocoa beans. Data presented by the International Monetary Center (ITC) states that the 4 plantation commodities are one of the top 20 products listed in the order of Indonesia's potential exports to the world (International Trade Center, 2020).

Based on Figure 1, sourced from the International Trade Center, it is noted that the largest export value

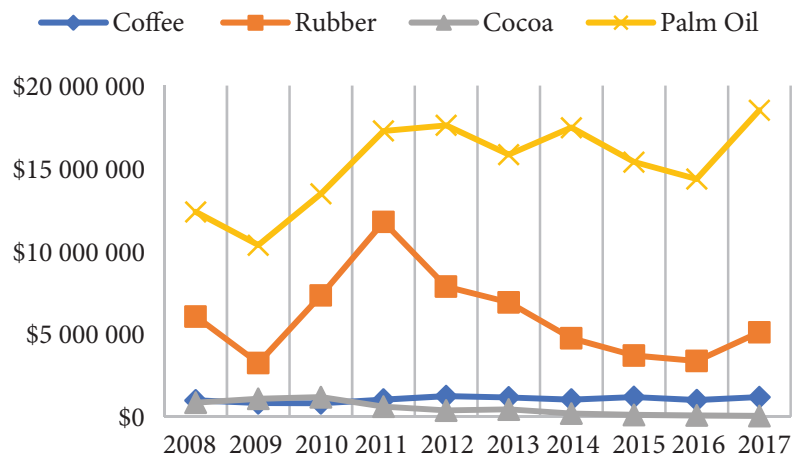

Figure 1. Export value of 4 Plantation Commodities (Coffee, Rubber, Cocoa, Palm oil) in millions of USD 2008-2017 (source: International Trade Center, 2018)

*Corresponding author. E-mail: erlambang@gmail.com 
of palm oil through Indonesian palm oil commodities in 2017 was US $\$ 18,513,121$. For coffee bean products through the commodity raw (not roasted) coffee beans, the largest export value in 2017 amounted to $1,187,157$ US \$. In rubber products through raw rubber commodities, the export value of Indonesia's raw rubber was the largest in 2010 amounting to US $\$ 1,190,740$, while in cocoa products through cocoa beans the largest export value in 2017 was US \$18,513,121.

In 2010, the export of cocoa seeds commodity of Indonesia was the highest. Yet, it consistently decreased annually down to the third position in 2016. This decrease happened due to the competition with Malaysia who started to become the main exporter of cocoa seeds and the derivative products among other ASEAN countries (Darmawan \& Nuryanti, 2011).

The export value of palm oil in 2016 in Indonesia succeeded to increase significantly up to 89.727 million USD (ASEAN Statistical Book, 2018). The total production of global palm oil in 2010 was 46.7 tons wherein Indonesia and Malaysia occupied $85.22 \%$ share of palm oil production worldwide. The share of Indonesia's CPO was 22.1 million tons while Malaysia was 17.7 million tons. On another side, Indonesia has not been able to compete with Malaysia in the palm oil downstream industry (Nayantakaningtyas \& Daryanto, 2012).

In the coffee commodity market, Vietnam was the country who had the biggest export value from 2010 to 2016 among ASEAN countries. The Philippines was a country with the least value among the five countries (Malaysia, the Philippines, Thailand, Indonesia and Vietnam) in terms of coffee seeds export. Moreover, in 2014 and 2015, the country recorded having no export of coffee seeds.

Furthermore, for the rubber commodity market, Thailand leads international trade for the last 7 years. The export of the five countries showed a declining trend until 2016, especially in Thailand. Indonesia was on the second position in 2010, only to be moved downward by Vietnam in 2012. This decline happened due to Indonesia's lack of competence in processing rubber into products with high additional values and competitiveness (Tampubolon et al., 2017).

The detrimental condition of export value in the 4 major plantation commodities in Indonesia would lead to a deficit in the balance of trade if it is not handled properly. Therefore, it is concerned that it will cause a decline in public welfare. Therefore, the attempts to identify the positive and negative impacts of the international agreement Indonesia participates in are important. The impacts include trade creation or trade diversion within the plantation commodities trade, specifically coffee, rubber, palm oil, and cocoa as the consequence of Indonesia's involvement in ACFTA.

The agreement of free trade generally causes both positive and negative impacts namely trade creation or trade diversion. Trade creation refers to a condition that creates a trade that did not exist before, as a result of the implementation of the trade agreement, which is ACFTA. Accordingly, the public welfare will be improved due to the increase in the intensity of international trade. On the other hand, trade diversion refers to a condition of welfare declining due to the actualization of the ACFTA itself. This is possible to happen if ACFTA pushes aside the imported goods from countries that are not members, which relatively have an advantage compared to the member countries (Yang \& Martinez, 2014; Szalanczi \& Trinh, 2017).

As a comparison, several previous studies found that there was a trade diversion in international trade, which was the interregional trade of European Union in the EFTA. Mexican trade in the NAFTA agreement. Indonesia's export trade of 2017-2012 in the ASEAN Korea Free Trade Area (AKFTA) (Sukma, 2014). Meanwhile, a trade creation was found in Indonesia's export in the trade of ASEAN Japan Comprehensive Economic Partnership (AJCEP).

Based on the background discussed above, it is important to analyze the impact of ACFTA agreement on the export of the 4 major plantation commodities (including coffee, cocoa, rubber, and palm oil) in Indonesia using the analytical method of international trade impacts which have a valid and sensitive response toward the change of macroeconomic condition and global commodity price on the export movement. The method is the generalized method of moment (GMM).

\section{Research novelty}

The differences between this study and the previous ones include: Firstly, based on our knowledge, there has no study which analyzed the impact of ACFTA on Indonesia's major plantation commodities. Secondly, involving the global commodity price of palm oil, rubber, coffee, and cocoa seeds in accordance with the model of each commodity. Thirdly, by applying the Generalized Method of Moment (GMM), this study will acquire the more valid and sensitive responses on the change of macroeconomic condition and global commodity price on the export movement of plantation commodity. Okabe (2014) conducted a study that aimed to examine the impact of AFTA existence in the inter-ASEAN trade using the gravity model of trade approach. The creation of trade is positively and significantly by the removal of tariffs of mass production. This study also found that the elasticity of tariffs reduction tends to influence imports compared to exports. Yang and Martínez (2014) used the gravity model of trade to investigate the phenomenon occurred due to the presence of ASEAN FTA (AFTA). AFTA constituted a trade creation. AFTA had a positive and significant relationship to the performance of export, especially in plantation and manufacture commodities. This increase did not only happen to member countries but also countries outside the AFTA agreement. 
Szalanczi and Trinh (2017) conducted research on trade creation and trade diversion during the implementation of the ASEAN-Japan Comprehensive Economic Partnership (AJCEP) using the gravity model of trade. They explained that AJCEP constituted trade creation between the member countries. They stated that the further the distance between two countries implementing the trade, then by joining into AJCEP they may reduce the transaction cost. Karemera et al. (2015) studied five FTA including ASEAN in the trade of beef and pork using a gravity model of trade. The findings indicate that the effect of trade diversion was found in ASEAN from countries that were not members to member countries.

\section{Literature review}

\section{Trade creation and trade diversion}

Viner (1950) argued that there are two impacts that may happen after the implementation of the free trade agreement, such as trade creation and trade diversion. Trade Creation will happen if part of the domestic production of a member country is replaced by imports which price is far lower than from other member countries with an assumption that all the resources have been utilized optimally (full employment). The positive impact is not only applicable to member countries but also to non-member countries due to the improvement of product specialization that can stimulate the increase of import from other countries.

The opposite of trade creation is trade diversion. This happens if a cheap import from other non-member countries is replaced by imports that are truly expensive (less efficient production) from one of the member countries and the diversion can cause the domestic production to fall down. The impact of Trade Creation and Trade Diversion can increase or decrease the welfare depending on which effect is more influential. Vinner's theory is later known as Vinner model.

This study uses the variable of macroeconomy which has influence toward Indonesia's export, namely GDP, exchange rate, consumption per capita, price index of export goods, and logistics performance index (LPI). Kumar (2014) explains in an empirical study that depreciation can encourage the export volume, Linder (1961) argued that countries which level of income is on the same or similar level tend to conduct trade. Dee and Findlay (2006) stated that the facilitation of trade indicated that the quality of infrastructures is relevant to the significant increase in trade.

Herleni (2018) stating that there is no trade diversion on ACFTA impact on the export and import. Szalanczi and Trinh (2017) state that AJCEP results in the creation of trade creation among member countries. The farther the distance between the two countries that do trade, then by joining the AJCEP they can reduce the cost. Ikhsan et al. (2016) state that accompanied by an increase in world prices rises in crude palm oil export tax. Junko
(2015) state that export is influenced by several things, one of them by the exchange rate of some countries

Esposito (2016) state that trade creation and trade diversion effect is estimated as a structural change in the relationship between trade flows, financial clearing, growth, price, and size of globalization. Karemera et al. (2015) state that the effects found in the ASEAN trade diversion from non-member states, to the member states. So that member states tend to divert their exports to other member states. Okabe (2014) stated that the tariff reduction is more inclined elasticity effect on imports than in exports. Thom (2017) stated that the depreciation of the real exchange rate is positively related to the balance of trade in a longer time horizon.

\section{Methods}

This study uses secondary data from several relevant sources. The type of data used is the panel of data from 2007 to 2017 on 5 ASEAN countries that have become the segment of the major plantation commodities export of Indonesia, China, and the 10 countries of the export segment in each plantation commodity. The data of this study sourced from the International Trade Center (ITC) and World Bank. The dependent variable in this study includes the export of plantation commodities namely coffee, rubber, cocoa, and palm oil. The independent variables in this study include the GDP, real exchange rate, logic performance index, price index of export goods, and consumption per capita and dummy ACFTA. The Dummy ACFTA has zero value if both countries are the member of ASEAN-China free trade area agreement and have the value of 1 if the trade partner is not a member of ASEAN-China free trade area agreement. The coefficient of dummy ACFTA has a positive value depicting the trade creation and coefficient with a negative value depicts trade diversion. The export data gained from the International Trade Center (ITC), GDP data, Exchange Rate, consumption, LPI, and price index of export goods obtained from the World Bank.

After the data are collected, the analytical tool used is the Generalized Method of Moment (GMM) that is an estimation of the parameter in regression. This method is developed from the theory of error term used to examine a theory or phenomenon developing toward research empirical data. The estimation of the GMM method using an instrumental variable that has a correlation with a relevant variable yet does not have a correlation with error term in the model (Nielsen, 2005). There are two procedures of estimation used in the GMM method, such as the first difference GMM and system GMM. The principle of first difference within the GMM method is used to cope with the endogeneity caused by the autocorrelation between regressor and error term (Arellano \& Bond, 1991; Blundell \& Bond, 1998). Meanwhile, the basic idea used in the system GMM method is to deal with the problems of the weak instrument within the equation of first difference 
(Blundell \& Bond, 1998). The use of GMM method is expected to investigate the major influence from the independent variables to the dependent variables.

\section{GMM specification test}

The validity of additional instruments can be acknowledged by using the Sargan/Hansen to over-identifying restriction. This examination is conducted to determine the validity of the model used. Zero Hypothesis (H0) in Sargan/Hansen test is over-identifying restriction valid. If the probability value is above the level of significance of $1 \%$, $5 \%$, or $1 \%$, then the model can be considered valid and the zero hypothesis ( $\mathrm{H} 0)$ is confirmed. If the probability value of chi-square is under the level of significance of $1 \%$, $5 \%$, or $10 \%$, then the $\mathrm{H} 0$ is denied or the model is invalid.

Furthermore, the autocorrelation test in Arellano Bond, the zero hypotheses ( $\mathrm{HO})$ in this examination has no autocorrelation. In the Aurellano Bond test, there is a $\mathrm{z}$ probability value, wherein if the probability value is below the level of significance of $1 \%, 5 \%$, or $10 \%$, then the $(\mathrm{H} 0)$ is denied, which indicates the existence of autocorrelation within the model thus it is invalid. On the contrary, if the probability value is above the level of significance of $1 \%$, $5 \%$, or $10 \%$, then the $(\mathrm{H} 0)$ is not denied and indicates the absence of autocorrelation thus the model is valid.

\section{Statistical test \\ Partial test ( $t$-test)}

The t-test is used to conduct an examination of the coefficient of the independent variables partially. This test is conducted to investigate the level of significance from the independent variables individually in influencing the dependent variables. The test is conducted by comparing the $\mathrm{t}$-value on the result of estimation with $\mathrm{t}$-table. If the $\mathrm{t}$-value $\geq \mathrm{t}$-table, then $\mathrm{HO}$ is denied and $\mathrm{H} 1$ is confirmed, which means that there is a relationship between the dependent and independent variables. The test can also be conducted by acknowledging the $\mathrm{p}$-value of $\mathrm{t}$-test if it is below the level of significance of $1 \%, 5 \%$, or $10 \%$, then there is a relationship between the dependent and independent variables.

\section{Simultaneous test $(\mathrm{Pob}>\mathrm{F})$}

Prob $>\mathrm{F}$ is used to determine the significance of the independent variables simultaneously in influencing the dependent variables. The simultaneous test is conducted by looking at the significance of prob $>$ chi2. If the probability value of chi2 is below the level of significance of $1 \%$, $5 \%$ or $10 \%$, then the $\mathrm{H} 0$ is denied and $\mathrm{H} 1$ is confirmed, which indicates that the independent variables are simultaneously influential to the dependent variables.

The basic model of this study refers to (Esposito, 2016) and (Yang \& Martinez, 2014) by modifying the model in accordance with the study objectives. To investigate the indication of trade diversion and trade creation post-ASEAN-China Free Trade Area and the segment of exporter countries specifically on the prioritized plantation commodities including coffee seed, cocoa seed, palm oil, and rubber, then it can be formed equation model of Dynamic Generalized Method of Moment (GMM) panel as follows:

$$
\begin{aligned}
& \ln E X_{-} \text {kopi }_{i j t}=\ln E X_{-} \text {kopi }_{i j t-1}+\beta_{1} \ln G D P_{i j t}+\beta_{2} \ln \text { Cons }_{i j t}+ \\
& \beta_{3} \ln R E R_{i j t}+\beta_{4} \ln E X P I_{i j t}+\beta_{5} \ln L P I_{i j t}+\beta_{6} D \ln A F T A_{i j}+e_{i t j} ; \\
& \ln E X_{-} \text {Sawit }_{i j t}=\ln E X_{-} \text {Sawit }_{i j t-1}+\beta_{1} \ln G D P_{i j t}+\beta_{2} \ln \text { Cons }_{i j t}+ \\
& \beta_{3} \ln R E R_{i j t}+\beta_{4} \ln E X P I_{i j t}+\beta_{5} \ln L P I_{i j t}+\beta_{6} D \ln A F T A_{i j}+e_{i t j} ; \\
& \ln E X_{-} \text {kakao }_{i j t}=\ln E X_{-} \text {kakao }_{i j t-1}+\beta_{1} \ln G D P_{i j t}+\beta_{2} \ln \text { Cons }_{i j t}+ \\
& \beta_{3} \ln R E R_{i j t}+\beta_{4} \ln E X P I_{i j t}+\beta_{5} \ln L P I_{i j t}+\beta_{6} D \ln A F T A_{i j}+e_{i t j} ; \\
& \ln E X_{\text {karet }_{i j t}}=\ln E X_{\text {karet }_{i j t-1}}+\beta_{1} \ln G D P_{i j t}+\beta_{2} \ln \text { Cons }_{i j t}+ \\
& \beta_{3} \ln R E R_{i j t}+\beta_{4} \ln E X P I_{i j t}+\beta_{5} \ln L P I_{i j t}+\beta_{6} D \ln A F T A_{i j}+e_{i t j} .
\end{aligned}
$$

Notes:

$i$ : Indonesia;

j: 5 ASEAN countries and China and 10 countries of export segment in plantation commodities Negara;

$\ln E X \_k o p i_{i j t}$ : Export of Indonesian Coffee to $j$ country on $t$ year (thousand USD), in natural $\log (\ln )$;

lnEX_Sawit ${ }_{i j t}$ : Export of Indonesian Palm oil to $j$ country on $t$ year (thousand USD), in natural $\log (\ln )$;

lnEX_kakao $i j t$ : Export of Indonesian Cocoa to $j$ country on $t$ year (thousand USD), in natural $\log (\ln )$;

lnEX_karet ${ }_{i j t}$ : Export of Indonesian Rubber to $j$ country on $t$ year $t$ (thousand USD), in natural $\log (\ln )$;

$R E R_{i j t}$ : Value of real exchange rate of $j$ country with $i$ country in year of $t$ (Rupiah), in the natural logarithm $(\ln )$;

$G D P_{i j t}$ : Real Total GDP of $i$ and $j$ countries in $t$ year (USD), in the natural logarithm (ln);

Cons $_{i j t}$ : Consumption of $i$ and $j$ countries in $t$ year (USD), in the natural logarithm (ln);

$E X P I_{i j t}$ : Price index of import goods of $i$ and $j$ countries in year $t$ (USD), in the natural logarithm (ln);

$L P I_{i j t}$ : Average value of Logistic Performance Index of $i$ and $j$ countries in year of $\mathrm{t}$ in the natural logarithm (ln)

$D_{\text {DAFTA }}$ : : Dummy of trade block to see the trade creation and trade diversion. The dummy variable will have a value of 1 if Indonesia's trade partner countries are nonASEAN-China countries and will have a value of 0 (zero) on the reversed case. There is a trade creation effect if the coefficient of this variable has a positive and sifnificant value and a trade diversion if the coefficient of this variable has a negative and significant value.

\section{Discussion}

Proxy of the free trade impact is shown on the dummy variable of ACFTA that indicates the influence of trade creation and trade diversion. The following is the result table (Table 1) of GMM System Estimator (Export): 
Table 1. GMM System Estimator (Export) Result (source: Output STATA 14)

\begin{tabular}{|c|c|c|c|c|}
\hline \multirow{2}{*}{ Variable } & \multicolumn{4}{|c|}{ Export Commodity } \\
\hline & Coffee & Rubber & Cocoa & Palm Oil \\
\hline L.Export & $-0.364^{* * *}$ & $0.930^{* * *}$ & $1.08^{\star *}$ & $0.174^{\star * *}$ \\
\hline GDP & $-1.236^{* *}$ & $0.339^{* * *}$ & $-0.442^{\star *}$ & $4.157^{\star * *}$ \\
\hline RER & $-0.815^{\star * *}$ & 0.005 & 0.112 & 0.014 \\
\hline LPI & $3.406^{\star * *}$ & $-2.311^{\star * *}$ & 1.427 & 0.127 \\
\hline Consumption & $1.687^{\star * *}$ & $-0.173^{\star}$ & 0.300 & $-4.036^{\star * *}$ \\
\hline $\begin{array}{l}\text { Price Index of } \\
\text { Export Goods }\end{array}$ & $-0.561^{\star *}$ & $-0.249^{* * *}$ & $0.369^{* * *}$ & $0.664^{* * *}$ \\
\hline ACFTA & $1.349^{\star * *}$ & $0.211^{* * *}$ & $-0.502^{\star}$ & $0.001^{* * *}$ \\
\hline $\operatorname{AR}(1)$ & 0.416 & 0.134 & 0.048 & 0.048 \\
\hline $\operatorname{AR}(2)$ & 0.576 & 0.008 & 0.208 & 0.208 \\
\hline Sargan Test & 0.456 & 0.000 & 0.864 & 0.864 \\
\hline Hansen Test & 0.182 & 0.619 & 0.969 & 0.969 \\
\hline $\begin{array}{l}\text { Hansen Test } \\
\text { (GMM) }\end{array}$ & 0.038 & 0.289 & 0.754 & 0.754 \\
\hline $\begin{array}{l}\text { Hansen Test } \\
\text { (Diff GMM) }\end{array}$ & 0.998 & 0.997 & 0.996 & 0.996 \\
\hline Hansen (IV) & 0.030 & 0.330 & 0.986 & 0.986 \\
\hline Hansen (Diff IV) & 0.855 & 0.913 & 0.482 & 0.482 \\
\hline Prob $>$ F & 0.000 & 0.000 & 0.000 & 0.000 \\
\hline $\begin{array}{l}\text { Number of } \\
\text { Instrumen }\end{array}$ & 18 & 25 & 22 & 25 \\
\hline Numbe of Group & 16 & 16 & 16 & 16 \\
\hline
\end{tabular}

Note: Regression Estimation ${ }^{*},{ }^{* *},{ }^{* * *}$ indicates a significance on the level of $10 \%, 5 \%, 1 \%$.

In the generalized method of moment, the identification test of over-identifying restriction is conducted to determine the validity of the model used. The test used the sargan/hansen test which distributed chi-square statistics. The estimation result of GMM system shows a value of hansen test above the level of significance of $1 \%, 5 \%$ or $10 \%$, then the model is confirmed value or the zero hypothesis (H0) is confirmed.

To investigate whether there is an autocorrelation between variables, then the Arellano-Bond for AR (2) is applied, an autocorrelation test of the distributed z-statistics. On the 10 commodities of Indonesia's main export, it is acknowledged that the result of the AR (2) test is above the level of significance of $1 \%, 5 \%$ or $10 \%$. Then the AR (2) $\mathrm{HO}$ is confirmed and it indicates the absence of autocorrelation within the model.

The simultaneous test is used to determine the significance of the independent variables simultaneously in influencing the dependent variables, by looking at the influence of simultaneous test using prob $>\mathrm{F}$ on whether it is less than the significance level of $1 \%, 5 \%$, or $10 \%$. The estimation result of GMM-Sys shows the value of prob $>\mathrm{F}$ of 0.000 which means the probability value in the area of $\mathrm{H} 0$ is denied with a significance level of $1 \%$ thus the variables of GDP, Exchange Rate, Logistics Performance Index (LPI), consumption, dummy, expi, and FTA.
The partial test is used to acknowledge the significance level of each independent variable individually in influencing the dependent variables. The estimation results of Sys GMM, the probability value of 0.000 from the lag of the dependent variables shows that the export of 5 Indonesia's plantation commodities still have a correlation between the time, therefore, this analysis contains a dynamic relationship. The variables of GDP, Exchange Rate, Logistic Performance Index (LPI), consumption, dummy, EXPI, and FTA on the export of 5 Indonesias plantation commodities indicates a positive and significant coefficient value on the level of $1 \%, 5 \%$, and $10 \%$, which shows that the variables significantly influence the total variables of export of 5 Indonesia's commodities with the 5 ASEAN countries and China and 10 countries with the biggest export segment of Indonesia. The positive coefficient value on the variable of macroeconomy shows that when there is an increase in GDP, Exchange Rate, Logistic Performance Index (LPI), consumption, and EXPI, then there will be an increase in Indonesia's export trade. The negative coefficient value in the variable of macroeconomy shows that when there is an increase in the macroeconomy variable, then there will be a decrease in Indonesia's export trade.

The variable of GDP in the commodities of coffee, rubber, cocoa, and palm oil based on the estimation result, has a coefficient value respectively of $-1.236,0.339$, -0.442 , and 4.157 which is significant to the level of $1 \%$ and 5\%. Junko (2015) explained that the national income per capita reflects the ability to export or import. Karagöz (2016) found that increased real global income has a positive relationship with export. Increase in GDP tends to encourage consumption thus producers will prefer to fulfill the domestic market (Adi, 2018). The phenomenon found in the research of Rose and Yellen (1989), Junko (2015) states that national income in the form of per capita reflects the ability to export or import.

The variable of RER (exchange rate) in the commodities of coffee, cocoa, and palm oil, based on the estimation result, has a coefficient value of -0.815 , which is significant on the level of $1 \%$. Yet, in the commodities of rubber, cocoa, and palm oil have insignificant influence with the coefficient values of $0.005,0.112$, and 0.014 . It implicates that the depreciation on the exchange rate can lower the export trade and vice versa. When the value of the currency is depreciated/devaluated, the goods produced within the country will become cheap and goods from other countries will become expensive, thus encourage export (Ariana, 2014). Stated that Rupiah weakening indirectly constitutes an opportunity to increase export. Kumar (2014) explained in an empirical study that depreciation can promote export volume directly.

The variable of Logistics Performance Index (LPI) in the commodities of coffee and rubber, based on the estimation result, has coefficient values of 3.406 and -2.311 , which is significant on the level of $1 \%$. Yet, in the commodities of cocoa and palm oil, it has insignificant influence with coefficient values of 01.427 and 0.127 . the Logistics Performance Index positively and significantly 
influences export (Gani, 2017). Dee and Findlay (2006) stated that the trade facilities indicate that the quality of infrastructure is related to a significant trade increase. Yet, in Indonesia, the increase of quality of logistic performance index that is not balanced with a declining logistics cost, Indonesia's logistics cost reached up to $23.5 \%$ in 2017 and was still left behind compared to other ASEAN countries, such as Vietnam (15\%), Thailand (13.2\%), Malaysia (13\%), and Singapore (8.1\%) (Budhiman, 2018).

The variable of consumption in the commodities of coffee, rubber, and palm oil, based on the estimation result, have coefficient values of $1.687,0.173$, and -4.036 , which are significant on the level of $1 \%$ and $10 \%$. Yet, in the commodity of cocoa, it has insignificant influence with a coefficient value of 0.300 . Big companies prefer to focus inside the country because they have been enjoying a big market power inside the country (Wagner, 2001). Therefore, when demands inside the country increase, the producers will prefer to market their products inside the country. The variable of Export Goods Index in the commodities of coffee, rubber, cocoa, and palm oil, based on the estimation result, has coefficient values of -0.561 , $-0.249,0.369$, and 0.664 , which are significant on the level of $1 \%, 5 \%$, and $10 \%$. Darhyati and Rifin (2017) also explain that countries with high purchasing power can increase their demand for import needs, thereby increasing demand for exporting countries.

The variable of dummy FTA in the commodities of coffee, rubber, cocoa, and palm oil, based on the estimation result, has coefficient values of $1.349,0.211$, and 0.001 which are significant on the level $1 \%$, in other words, the $\mathrm{HO}$ is denied therefore there is an export trade between Indonesia and ASEAN-China countries and non-member countries. The positive and significant coefficient values in the variable of dummy FTA indicate that there is an impact of trade creation in the export (Szalanczi \& Trinh, 2017; Yang \& Martinez, 2014). In the commodity of cocoa, it has a coefficient value of -0.502 which means the $\mathrm{HO}$ is denied therefore there is an export trade between Indonesia and ASEAN-China countries and non-member countries. The export trade between Indonesia and ASEANChina countries on average is increased by $1.349 \%$, $0.211 \%$, and $0.001 \%$ in the commodities of coffee, rubber, and palm oil without any decrease in export from nonmember countries of ACFTA. In the commodity of cocoa, there is a trade diversion between the member countries with non-member countries as much as $0.502 \%$. Hapsari and Mangunsong (2006) revealed the existence of trade diversion within 5 ASEAN countries. International trade theory states that the agreement on free trade, namely the Free Trade Agreement, is able to encourage trade between countries (Widyasanti, 2010).

\section{Conclusions}

The independent variables in this study including the GDP, real exchange rate, logic performance index, price index of export goods, and consumption on average have an influence to the export of Indonesia's plantation commodities. Yet, there are some independent variables that have insignificant influence toward the dependent variables, such as the variable of the exchange rate in the commodity of rubber, cocoa, and palm oil, variable of logistics performance index in the commodity of cocoa and palm oil, consumption in the commodity of cocoa. The implementation of ACFTA, which is aimed at the dummy ACFTA shows a result of trade creation in the commodity of coffee, rubber, and palm oil with the coefficient values of $1.349,0.211$, and 0.001 . Yet, in the commodity of cocoa, it shows a trade diversion with a coefficient value of 0.502 thus there is a trade diversion between member and nonmember countries.

\section{Recommendation}

Based on the analysis of trade creation and trade diversion using the GMM method, the variable of logistics performance index on average has a positive influence toward the export of Indonesia's plantation commodities. It is expected that with such influence, the government can optimize the improvement of infrastructures, which is one of the indicators in the establishment of the logistics performance index. After the implementation of the ASEAN Free Trade Area, Indonesia experiences the trade creation impact on the sectors of coffee, rubber, and palm oil export, to encourage such export improvement, the government is expected to be able to make policies which can support the export performance of Indonesia's plantation commodities through producers training, simplification of export permit, as well as brand introduction through exhibitions.

\section{References}

Adi, T. (2018). PDB Naik, Pajak makin Tinggi. Dapat diakses pada. https://analisis.kontan.co.id/news/pdb-naik-pajakmakin-tinggi

Arellano, M., \& Bond, S. (1991). Some tests of specification for panel data: Monte Carlo evidence and an application to employment equations. The Review of Economic Studies, 58(2), 1071-1086. http://people.stern.nyu.edu/wgreene/Econometrics/Arellano-Bond.pdf

Ariana, D. S. (2014). Trade Creation \& Trade Diversion ASEANKorea Free Trade Area: Studi Kasus Ekspor Indonesia Periode 2007-2012. Departemen Ilmu Ekonomi FEB UNAIR.

ASEAN Statistical Yearbook. (2018). ASEAN Statistical Yearbook. The ASEAN Secretariat.

https://asean.org/storage/2018/12/asyb-2018.pdf

Blundell, R., \& Bond, S. (1998). Initial conditions and moment restrictions in dynamic panel data models. Journal of Econometrics, 87(1), 115-143.

https://doi.org/10.1016/S0304-4076(98)00009-8

Budhiman, I. (2018). Indeks Logistik Indonesia Naik, tapi Biaya Logistik masih Tinggi. Dapat diakses pada.

https://ekonomi.bisnis.com/read/20180725/98/820509/indeks-logistik-indonesia-naik-tapi-biaya-logistik-masih-tinggi

Darhyati, A. T., \& Rifin, A. (2017). Impact of non tariff measure on Indonesian cocoa exports. International Journal of Agriculture System, 5(2), 175-184.

https://doi.org/10.20956/ijas.v5i2.1191 
Darmawan, A., \& Nuryanti, S. (2011). Analisis Dampak AFTA \& Kebijakan Perdagangan Kakao di Pasar Domestik \& China. Analisis Kebijakan Perkebunan, 9, 143-156.

https://doi.org/10.21082/akp.v9n2.2011.143-156

Dee, P., \& Findlay, C. (2006). Trade facilitation: what, why, how, where and when? Working paper, Asian Development Bank, Manila.

Esposito, P. (2016). Trade creation, trade diversion and imbalances in the EMU. Economic Modelling, 60(c), 462-472. http://iranarze.ir/wp-content/uploads/2017/01/E3442.pdf

Gani, A. (2017). The logistics performance effect in international trade. The Asian Journal of Shipping and Logistics, 33(4), 279288. https://doi.org/10.1016/j.ajsl.2017.12.012

Hapsari, I. M., \& Mangunsong, C. (2006). Determinants of ACFTA Members' trade flows and potential for trade diversion. Asia-Pacific Research and Training Network on Trade Working Paper Series, 7(1), 53-59.

https://ideas.repec.org/p/esc/wpaper/2106.html

Herleni. (2018). Analisis Trade Creation \& Trade Diversion Produk Industri Kreatif Fesyen Indonesia 20072016 Pasca Asean-China Free Trade Area \& 30 Negara Pangsa Fesyen Terbesar Dunia. Fakultas Ekonomi \& Bisnis. Universitas Airlangga.

Ikhsan, S., Anindita, R., Hanani, N., \& Koestiono, D. (2016). The change in world price and export tax of crude palm oil and their impact on the economy and welfare. RJOAS, 4(52) (April). https://doi.org/10.18551/rjoas.2016-04.05

International Trade Center. (2018). Data Ekspor. http://www.intracen.org/itc/market-info-tools/statistics-export-country-product-monthly/.

International Trade Center. (2020). Data Ekspor. https://www. trademap.org/Country_SelProductCountry

Junko, S. (2015). Abenomics, yen depreciation, trade deficit, and export competitiveness. In RIETI Discussion Paper. https://www.rieti.go.jp/jp/publications/dp/15e020.pdf

Karagöz, K. (2016). Determining factors of Turkey's export performance: an empirical analysis. Procedia Economics and Finance, 38, 446-457. https://doi.org/10.1016/S2212-5671(16)30216-7

Karemera, D., Koo, W., Smalls, G., \& Whiteside, L. (2015). Trade creation, diversion effects and exchange rate volatility in the global meat trade. Journal of Economic Integration, 30(2), 240-268.

https://doi.org/10.11130/jei.2015.30.2.240

Kumar, D. (2014). Correlations, return and volatility spillovers in Indian exchange rate. Global Business Review, 15(1), 77-91. https://journals.sagepub.com/doi/10.1177/0972150913515577

Linder, S. B. (1961). An essay on trade and transformation. John Wiley and Sons.
Nayantakaningtyas, J. S., \& Daryanto, H. K. (2012). Daya Saing \& Strategi Pengembangan Minyak Sawit di Indonesia. Jurnal Manajemen \& Agribisnis, 9(3), 194-201. https://journal.ipb. ac.id/index.php/jmagr/article/view/7893/6194

Nielsen, B. H. (2005). Generalized Method of Moments (GMM) estimation. In Econometrics. Department of Economics University of Copenhagen, Copenhagen.

Okabe, M. (2014). The impact of AFTA on intra-AFTA trade. Journal of Asian Economics, 35, 12-31. https://doi.org/10.1016/j.asieco.2014.09.004

Rose, A. K., \& Yellen, J. L. (1989). Is there a J-curve? Journal of Monetary Economics, 24(1), 53-68. https://doi.org/10.1016/0304-3932(89)90016-0

Sukma, A. (2014). Trade creation \& trade diversion AseanKorea free trade area: Studi Kasus Ekspor Indonesia Periode 2007-2012. Faculty of economic, University Airlangga.

Szalanczi, A., \& Trinh, M. (2017). trade creation and trade diversion effects of ASEAN-Japan Comprehensive Economic Partnership (AJCEP). Lund University, ID 8925019.

https://lup.lub.lu.se/student-papers/search/publication/8925019

Tampubolon, J., Ginting, A., Nainggolan, H. L., \& Aritonang, J. (2017). North Sumatra's export performance and competitive advantages in the implementation of ASEAN Economic Community (AEC). International Journal of Advance Agricultural Research, 5, 61-65. http://www.bluepenjournals.org/ ijaar/pdf/2017/August/Tampubolon_et_al.pdf

Thom, T. X. (2017). Exchange rate, trade balance, and the J-Curve effect in Vietnam. Asian Economic and Financial Review, 7(9), 858-868. https://doi.org/10.18488/journal.aefr.2017.79.858.868

Viner, J. (1950). The Customs Union issue. Carnegie Endowment for International Peace.

Wagner, J. (2001). A note on form size: export bahaviour relationship. Small Business Economics, 17, 229-237. https://doi.org/10.1023/A:1012202405889

Widyasanti, A. A. (2010). Perdagangan Bebas Regional \& Daya Saing Ekspor: Kasus Indonesia. Buletin Ekonomi Moneter \& Perbankan, 13(10), 5-22.

https://doi.org/10.21098/bemp.v13i1.251

Yang, S., \& Martínez, Z. I. (2014). A Panel data gravity analysis of trade creation and diversion effects. China Economic Review, 29(Iso 690), 138. https://doi.org/10.1016/j.chieco.2014.04.002

Yang, S., \& Martinez, Z. I. (2014). China economic review: A panel data analysis of trade creation and trade diversion effects: The case of ASEAN-China Free Trade Area. China Economic Review, 29, 138-151. https://doi.org/10.1016/j.chieco.2014.04.002 